\title{
Analisis Efektivitas Pajak Hotel, Pajak Restoran dan Pajak Hiburan Serta Kontribusinya terhadap Produk Domestik Regional Brutto dan Pendapatan Asli Daerah di Kota Tegal
}

\author{
Asrofi Langgeng Noerman Syah \\ Politeknik Harapan Bersama \\ Tegal, Indonesia \\ asrofilanggeng@gmail.com
}

\author{
Andri Widianto \\ Politeknik Harapan Bersama \\ Tegal, Indonesia \\ andriwidi29@gmail.com
}

\author{
Elisa Purwitasari \\ Politeknik Harapan Bersama \\ Tegal, Indonesia \\ elisa.purwitasari@gmail.com
}

\begin{abstract}
ABSTRAK
Penelitian ini bertujuan untuk mengetahui efektivitas penerimaan pajak hotel, pajak restoran, dan pajak hiburan serta kontribusinya terhadap produk domestic regional bruto \& pendapatan asli daerah di Kota Tegal Tahun 2013-2017. Penelitian ini menggunakan data sekunder yang diperoleh dari Badan Keuangan Daerah Kota Tegal. Teknik analisa data yang digunakan adalah analisis deskriptif dengan uji efektivitas dan uji kontribusi. Hasil penelitian menunjukkan bahwa efektivitas penerimaan pajak hotel di Kota Tegal selama periode tahun 2013 - 2017 memiliki rasio lebih dari $100 \%$ sehingga dapat dikatakan sangat efektif. Efektivitas penerimaan pajak restoran di Kota Tegal selama periode tahun 2013 - 2017 memiliki rasio lebih dari 100\% sehingga dapat dikatakan sangat efektif. Efektivitas penerimaan pajak hiburan di Kota Tegal selama periode tahun 2013 - 2017 mengalami perubahan tiap tahunnya. Pada tahun 2013 rasio efektivitas penerimaan pajak hiburan sebesar 53,71\% sehingga dikatakan tidak efektif. Kemudian pada tahun 2014, rasio efektivitas penerimaan pajak hiburan sebesar $83,34 \%$ sehingga dikatakan cukup efektif. Sedangkan pada tahun 2015 - 2017, rasio efektivitas penerimaan pajak hiburan lebih dari 100\% sehingga dikatakan sangat efektif. Kontribusi pajak hotel, pajak restoran dan pajak hiburan terhadap Produk Domestik Regional Bruto (PDRB) Kota Tegal selama periode tahun 2013 - 2017 dengan rasio kontribusi masih dibawah 10\% sehingga dikatakan sangat kurang. Kontribusi pajak hotel, pajak restoran dan pajak hiburan terhadap Pendapatan Asli Daerah (PAD) Kota Tegal selama periode tahun 2013 - 2017 dengan rasio kontribusi masih dibawah $10 \%$ sehingga dikatakan sangat kurang.
\end{abstract}

Kata Kunci : Pajak Hotel, Pajak Restoran, Pajak Hiburan, Produk Domestik Regional Bruto, Pendapatan Asli Daerah

\section{Pendahuluan}

Indonesia merupakan negara yang terus berkembang dengan pembangunan yang dilakukan diberbagai sektor. Pembangunan nasional bertujuan untuk mewujudkan masyarakat yang adil dan sejahtera dengan memanfaatkan sumber daya yang dimiliki dari setiap daerah. Oleh karena itu pelaksanaan pembangunan nasional tidak bisa dilepaskan dengan adanya pembangunan daerah yang merupakan bagian integral dari pemerintah pusat sehingga pembangunan dapat dilaksanakan secara merata diseluruh Indonesia. Pembangunan daerah diarahkan untuk mengembangkan potensi daerah dan meningkatkan kemampuan dan daya guna keseluruhan tatanan, perangkat, kelembagaan, dan kebijakan keuangan dalam menunjang kesinambungan pembangunan dan peningkatan kemandirian bangsa. Indonesia menganut asas desentralisasi dengan memberikan kesempatan kepada pemerintah daerah dalam menyelenggarakan otonomi daerah yang berlaku efektif sejak Januari 2001.

Otonomi Daerah menurut UndangUndang Nomor 32 Tahun 2004 adalah hak, wewenang, serta kewajiban daerah otonom untuk mengatur serta mengurus sendiri urusan pemerintah dan kepentingan masyarakat setempat sesuai dengan peraturan perundang-undangan yang berlaku. Seiring dengan diberlakukannya otonomi daerah maka dikenal pula istilah desentralisasi fiskal. Desentralisasi fiskal berarti pendelegasian 
kewenangan dan tanggung jawab fiskal dari pemerintah pusat kepada pemerintah daerah. Dengan diberlakukannya kebijakan desentralisasi fiskal, maka daerah diberikan kebebasan untuk mengatur sistem pembiayaan dan pembangunan daerahnya sesuai dengan potensi dan kapasitasnya masing-masing. Otonomi daerah merupakan suatu konsekuensi reformasi yang harus dihadapi oleh setiap daerah di Indonesia, terutama kabupaten dan kota sebagai unit pelaksana otonomi daerah. Untuk melaksanakan otonomi daerah, pemerintah harus dapat cepat mengidentifikasi sektor-sektor potensial sebagai motor penggerak pembangunan daerah, terutama melalui upaya pengembangan potensi Pendapatan Asli Daerah (PAD).

Pendapatan Asli Daerah (PAD) merupakan sumber keuangan daerah yang digali dari dalam wilayah daerah yang bersangkutan yang terdiri dari pajak daerah, retribusi daerah, hasil pengelolaan kekayaan daerah yang dipisahkan, dan pendapatan asli daerah lain-lain yang sah. Pendapatan Asli Daerah (PAD) merupakan salah satu indikator yang menentukan derajat kemandirian suatu daerah. Semakin besar penerimaan PAD suatu daerah maka semakin rendah tingkat ketergantungan pemerintah daerah tersebut terhadap pemerintah pusat. Sebaliknya, semakin rendah penerimaan PAD suatu daerah maka semakin tinggi tingkat ketergantungan pemerintah daerah tersebut terhadap pemerintah pusat. Hal ini dikarenakan PAD merupakan sumber penerimaan daerah yang berasal dari dalam daerah itu sendiri.

Salah satu sumber PAD yang digunakan untuk pembangunan daerah adalah melalui Pajak Daerah dan Retribusi Daerah. Undang-Undang Nomor 28 Tahun 2009 Tentang Pajak Daerah dan Retribusi Daerah menetapkan ketentuan-ketentuan pokok yang memberikan pedoman kebijakan dan arahan bagi daerah untuk pelaksanaan pemungutan pajak dan retribusi, sekaligus membuat kebijakan pengaturan untuk menjamin keberhasilan penerapan Pajak Daerah dan Retribusi Daerah. Menurut Undang-Undang No. 28 Tahun 2009, jenis pajak daerah kabupaten/kota terdiri atas pajak reklame, pajak hotel, pajak restoran, pajak hiburan, pajak parkir, pajak penerangan jalan, pajak mineral bukan logam dan batuan, pajak sarang burung walet, pajak air bawah tanah, pajak bumi dan bangunan pedesaan perkotaan dan bea perolehan hak atas tanah dan bangunan.

Kota Tegal merupakan daerah kota yang terkenal dengan kota Bahari karena dekat dengan pantai termasuk dalam Provinsi Jawa Tengah. Kota Tegal merupakan daerah yang cukup strategis untuk pusat perekonomian karena berada di jalur pantura jawa. Salah satu penerimaan Pendapatan Asli Daerah di Kota Tegal adalah pajak daerah. Menurut Peraturan Daerah Kota Tegal No. 5 Tahun 2011 tentang pajak daerah, jenis pajak daerah dalam Peraturan Daerah tersebut terdiri atas: a. Pajak Hotel; b. Pajak Restoran; c. Pajak Hiburan; d. Pajak Reklame; e. Pajak Penerangan Jalan; f. Pajak Parkir; g. Pajak Sarang Burung Walet ; dan h. Pajak Bumi dan Bangunan Perdesaan dan Perkotaan.

Pajak hotel adalah pajak atas setiap pelayanan yang disediakan hotel dengan pembayaran, termasuk jasa penunjang sebagai kelengkapan hotel yang sifatnya memberikan kemudahan dan kenyamanan, termasuk fasilitas olahraga dan hiburan. Jasa penunjang sebagaimana dimaksud adalah fasilitas telepon, faksimile, teleks, internet, fotokopi, pelayanan cuci, seterika, transportasi dan fasilitas sejenis lainnya yang disediakan atau dikelola hotel.

Pajak Restoran adalah pajak yang dipungut atas setiap pelayanan yang disediakan restoran dengan pembayaran. Pelayanan yang disediakan Restoran meliputi pelayanan penjualan makanan dan/atau minuman yang dikonsumsi oleh pembeli, baik dikonsumsi di tempat pelayanan maupun di tempat lain.

Pajak hiburan adalah pajak atas setiap penyelenggaraan hiburan dengan dipungut bayaran. Hiburan meliputi: a. tontonan film; b. pagelaran kesenian, musik, tari dan/atau busana; c. kontes kecantikan, binaraga dan sejenisnya; d. pameran yang bersifat komersial; e. diskotik, karaoke, klab malam dan sejenisnya; f. sirkus, akrobat dan sulap; g. permainan bilyar, golf dan boling; h. pacuan kuda, kendaraan bermotor dan permainan ketangkasan ; i. panti pijat, refleksi, mandi uap/spa dan pusat kebugaran (fitness center); j. pertandingan olah raga berbagai cabang olah raga.

Pemerintah Kota Tegal melalui Badan Keuangan Daerah melakukan usaha-usaha peningkatan pajak-pajak tersebut secara optimal untuk mengisi pendapatan daerah. Hal ini juga di dukung oleh perkembangan perekonomian yang meningkat di Kota Tegal yang dapat dilihat dalam perkembangan PDRB Perkapita (Produk Domestik Regional Bruto). PDRB Perkapita merupakan jumlah nilai tambah yang dihasilkan oleh seluruh 
usaha dalam suatu wilayah, atau merupakan jumlah seluruh nilai dan jasa akhir yang di hasilkan oleh suatu daerah.

Akan tetapi, berdasarkan hasil observasi awal di Badan Keuangan Daerah Kota Tegal pada bulan Maret 2018 menunjukkan bahwa jumlah realisasi penerimaan pajak daerah di tahun 2017 mengalami penurunan dibandingkan dengan di tahun 2016. Pada tahun 2016, realisasi penerimaan pajak daerah Kota Tegal sebesar Rp. 83.260.277.715 sedangkan pada tahun 2017 sebesar Rp. 69.042.327.743. Hal tersebut sangat bertolak belakang dengan perkembangan bisnis di Kota Tegal yang dalam beberapa tahun terakhir mengalami perkembangan yang sangat pesat. Hal itu ditunjukkan dengan berdirinya beberapa hotel, rumah makan atau cafe, mall, pusat hiburan dan tempat hunian atau perumahan.

Berdasarkan uraian diatas maka peneliti tertarik untuk melakukan penelitian terkait Pajak Hotel, Pajak Restoran Dan Pajak Hiburan Di Kota Tegal sehingga dapat dirumuskan sebuah permasalahan dalam penelitian ini adalah bagaimana efektivitas penerimaan pajak hotel, pajak restoran dan pajak hiburan serta kontribusinya terhadap Produk Domestik Regional Bruto dan Pendapatan Asli Daerah di Kota Tegal.

Tujuan penelitian ini adalah untuk mengetahui efektivitas penerimaan pajak hotel, pajak restoran dan pajak hiburan serta kontribusinya terhadap Produk Domestik Regional Bruto dan Pendapatan Asli Daerah di Kota Tegal. Dari hasil penelitian ini dapat digunakan sebagai bahan pertimbangan dan masukan bagi Pemerintah Kota Tegal dalam menyusun kebijakan atau peraturan daerah untuk meningkatkan penerimaan daerah. Selain itu juga dapat dijadikan masukan bagi Badan Keuangan Daerah Kota Tegal untuk menyusun strategi/tata cara yang tepat dalam meningkatkan penerimaan dari sektor pajak daerah.

\section{Tinjauan Pustaka}

2.1. Produk Domestik Regional Bruto

Produk Domestik Regional Bruto (PDRB) adalah keseluruhan nilai tambah barang dan jasa yang dihasilkan oleh berbagai sektor ekonomi disuatu wilayah tertentu, dalam kurun waktu satu tahun. Ada dua jenis penghitungan PDRB, yaitu atas dasar harga berlaku (current year price) dan atas dasar harga konstan (base year price).
Menurut harga berlaku artinya nilai barang dan jasa dihitung berdasarkan harga pada tahun yang bersangkutan, yang berarti termasuk kenaikan harga-harga ikut dihitung. Sedangkan menurut harga konstan artinya nilai barang dan jasa yang dihasilkan, dihitung berdasarkan harga pada tahun dasar.(Nurrohman, 2010)

Semakin besar PDRB berarti pertumbuhan ekonomi suatu daerah semakin tinggi. Pertumbuhan ekonomi bersangkut paut dengan proses peningkatan produksi barang dan jasa dalam kegiatan ekonomi masyarakat. Jadi dapat dikatakan bahwa pertumbuhan ekonomi adalah proses dimana terjadi kenaikan PDRB. Semakin tinggi nilai PDRB suatu daerah, semakin besar pula potensi sumber penerimaan daerah tersebut (Thamrin, 2001 dalam Nurrohman, 2010). Bila pertumbuhan ekonomi meningkat, maka pendapatan dan kesejahteraan masyarakat akan meningkat pula. Dengan naiknya pendapatan masyarakat, maka tingkat konsumsi masyarakat akan meningkat pula, dan pada akhirnya dapat meningkatkan penerimaan pajak. Disamping itu semakin tinggi pendapatan seseorang, maka akan semakin tinggi pula kemampuan seseorang untuk membayar pajak (ability to pay) berbagai pungutan, seperti pajak yang ditetapkan oleh pemerintah daerah.

\subsection{Pendapatan Asli Daerah}

Pendapatan asli daerah menurut UndangUndang No 33 tahun 2004 adalah pendapatan yang diperoleh daerah yang dipungut berdasarkan Peraturan Daerah sesuai dengan peraturan perundang-undangan. Menurut Halim (2007) kelompok pendapatan asli daerah dipisahkan menjadi empat jenis pendapatan, yaitu :

1. Pajak Daerah, meliputi pajak propinsi dan pajak kabupaten/kota

2. Retribusi Daerah, meliputi retribusi jasa umum, jasa usaha, dan perijinan tertentu

3. Hasil perusahaan milik daerah dan hasil pengelolaan kekayaan daerah yang dipisahkan

4. Lain - lain pendapatan asli daerah yang sah, meliputi hasil penjualan kekayaan daerah yang tidak dipisahkan, hasil pemanfaatan atau pendayagunaan kekayaan daerah yang tidak dipisahkan, jasa giro, pendapatan bunga tuntutan ganti rugi, keuntungan selisih nilai tukar rupiah terhadap mata uang asing, dan komisi, potongan, ataupun bentuk lain sebagai 
akibat dari penjualan atau pengadaan barang atau jasa oleh daerah.

\subsection{Pajak Daerah}

Pajak daerah sesuai dengan UndangUndang No. 28 Tahun 2009 tentang Pajak Daerah, disebutkan bahwa pajak daerah adalah kontribusi wajib pajak kepada daerah yang tertuang oleh orang pribadi atau badan yang bersifat memaksa berdasarkan undang-undang, dengan tidak mendapatkan imbalan secara langsung dan digunakan untuk keperluan daerah bagi sebesarbesarnya kemakmuran rakyat.

Sumber-sumber penerimaan pajak daerah kabupaten/kota menurut Undang-Undang Nomor 28 Tahun 2009 adalah Pajak Hotel, Pajak Restoran, Pajak Hiburan, Pajak Reklame, Pajak Penerangan Jalan, Pajak Parkir, Pajak Mineral Bukan Logam dan Batuan, Pajak Air Tanah, Pajak Sarang Burung Walet, Pajak Bumi dan Bangunan Pedesaan dan Perkotaan, dan Bea Perolehan Hak atas Tanah dan Bangunan.

\subsection{Pajak Hotel}

Menurut Peraturan Daerah Kota Tegal No. 5 Tahun 2011, Pajak Hotel adalah pajak atas pelayanan yang disediakan oleh hotel. Hotel adalah fasilitas penyedia jasa penginapan/peristirahatan termasuk jasa terkait lainnya dengan dipungut bayaran, yang mencakup juga motel, losmen, gubuk pariwisata, wisma pariwisata, pesanggrahan, rumah penginapan dan sejenisnya, serta rumah kos dengan jumlah kamar lebih dari 10 (sepuluh).

Objek Pajak Hotel adalah pelayanan yang disediakan oleh hotel dengan pembayaran, termasuk jasa penunjang sebagai kelengkapan hotel yang sifatnya memberikan kemudahan dan kenyamanan, termasuk fasilitas olahraga dan hiburan. Jasa penunjang berupa fasilitas telepon, faksimile, teleks, internet, fotokopi, pelayanan cuci, seterika, transportasi dan fasilitas sejenis lainnya yang disediakan atau dikelola hotel.

Tidak termasuk Objek Pajak Hotel adalah: a. jasa tempat tinggal asrama yang diselenggarakan oleh Pemerintah atau Pemerintah Daerah; b. jasa sewa apartemen, kondominium dan sejenisnya; c. jasa tempat tinggal di pusat pendidikan atau kegiatan keagamaan; d. jasa tempat tinggal di rumah sakit, asrama perawat, panti jompo, panti asuhan, dan panti sosial lainnya yang sejenis; dan e. jasa biro perjalanan atau perjalanan wisata yang diselenggarakan oleh hotel yang dapat dimanfaatkan oleh umum. Dasar pengenaan Pajak Hotel adalah jumlah pembayaran atau yang seharusnya dibayar kepada Hotel dengan Tarif Pajak Hotel ditetapkan sebesar 10\% (sepuluh persen).

\subsection{Pajak Restoran}

Menurut Peraturan Daerah Kota Tegal No. 5 Tahun 2011, Pajak Restoran adalah pajak atas pelayanan yang disediakan oleh restoran. Restoran adalah fasilitas penyedia makanan dan/atau minuman dengan dipungut bayaran, yang mencakup juga rumah makan, kafetaria, kantin, warung, bar dan sejenisnya termasuk jasa boga/katering.

Objek Pajak Restoran adalah pelayanan yang disediakan oleh Restoran. Pelayanan yang disediakan Restoran meliputi pelayanan penjualan makanan dan/atau minuman yang dikonsumsi oleh pembeli, baik dikonsumsi di tempat pelayanan maupun di tempat lain. Tidak termasuk objek pajak restoran adalah pelayanan yang disediakan oleh restoran yang nilai penjualannya tidak melebihi Rp. 15.000.000,00 (lima belas juta rupiah) per bulan.

Subjek Pajak Restoran adalah orang pribadi atau Badan yang membeli makanan dan/atau minuman dari Restoran. Wajib Pajak Restoran adalah orang pribadi atau Badan yang mengusahakan Restoran. Dasar pengenaan Pajak Restoran adalah jumlah pembayaran yang diterima atau yang seharusnya diterima restoran. Tarif Pajak Restoran ditetapkan sebesar 10\% (sepuluh persen).

\subsection{Pajak Hiburan}

Menurut Peraturan Daerah Kota Tegal No. 5 Tahun 2011, Pajak Hiburan adalah pajak atas penyelenggaraan hiburan. Hiburan adalah semua jenis tontonan, pertunjukan, permainan dan/atau keramaian yang dinikmati dengan dipungut bayaran. Objek Pajak Hiburan adalah jasa penyelenggaraan Hiburan dengan dipungut bayaran. Hiburan sebagaimana dimaksud meliputi : a. tontonan film; b. pagelaran kesenian, musik, tari dan/atau busana; c. kontes kecantikan, binaraga dan sejenisnya; d. pameran yang bersifat komersial; e. diskotik, karaoke, klab malam dan 
sejenisnya; f. sirkus, akrobat dan sulap; g. permainan bilyar, golf dan boling; h. pacuan kuda, kendaraan bermotor dan permainan ketangkasan ; i. panti pijat, refleksi, mandi uap/spa dan pusat kebugaran (fitness center); j. pertandingan olah raga berbagai cabang olah raga.

Tidak termasuk objek pajak sebagaimana dimaksud adalah pagelaran kesenian rakyat/tradisional dalam rangka usaha pelestarian kesenian dan budaya tradisional daerah dan pagelaran kesenian yang bernuansa keagamaan (religius). Subjek Pajak Hiburan adalah orang pribadi atau Badan yang menikmati hiburan. Wajib Pajak Hiburan adalah orang pribadi atau Badan yang menyelenggarakan hiburan. Dasar pengenaan Pajak Hiburan adalah jumlah uang yang diterima atau yang seharusnya diterima oleh penyelenggara Hiburan. Jumlah uang yang seharusnya diterima sebagaimana dimaksud termasuk potongan harga dan tiket cuma-cuma diberikan kepada penerima jasa Hiburan. berikut :

Tarif Pajak Hiburan ditetapkan sebagai

a. tontonan film sebesar $25 \%$

b. pagelaran kesenian, musik, tari dan/atau busana sebesar $20 \%$

c. kontes kecantikan, binaraga dan sejenisnya sebesar $25 \%$

d. pameran yang bersifat komersial sebesar $10 \%$

e. diskotik, karaoke, klab malam dan sejenisnya sebesar 50\%

f. sirkus, akrobat dan sulap sebesar $30 \%$

g. permainan bilyar, golf dan boling sebesar $30 \%$

h. pacuan kuda, kendaraan bermotor \& permainan ketangkasan sebesar 30\%

i. panti pijat, refleksi, mandi uap/spa dan pusat kebugaran (fitnes center) sebesar 35\%

j. pertandingan olah raga berbagai cabang olah raga sebesar $15 \%$

\section{Metode Penelitian}

Jenis data yang digunakan adalah data kuantitatif dan sumber data yang digunakan adalah data sekunder. Metode pengumpulan data dilakukan dengan wawancara, observasi dan studi pustaka. Metode analisis data yang digunakan dalam penelitian ini adalah analisis deskriptif. Dalam penelitian ini akan digunakan analisis data kuantitatif serta analisis data secara kualitatif untuk menganalisis data dalam bentuk uraian dengan menggunakan kata-kata. Adapun analisis deskriptif dalam penelitian ini terdiri atas uji efektivitas dan uji kontribusi. Efektivitas penerimaan pajak hotel, pajak restoran dan pajak hiburan dapat dihitung dengan menggunakan rumus berikut ini :

$$
R E=\frac{\text { realisasi terima pajak }}{\text { potensi/target terima pajak }} \times 100 \%
$$

Keterangan :

$\mathrm{RE}=$ Rumus Efektivitas

Untuk mengetahui kontribusi pajak hotel, pajak restoran dan pajak hiburan terhadap PDRB dan PAD digunakan rumus kontribusi berikut ini :

Rumus kontribusi $=\frac{\text { penerimaan pajak }}{P D R B / P A D} \times 100 \%$

\section{Hasil dan Pembahasan}

\subsection{Efektivitas Pajak Hotel}

Berdasarkan data target dan realisasi penerimaan pajak hotel selama periode tahun 2013 - 2017 maka dapat diketahui rasio efektivitas penerimaan pajak hotel di Kota Tegal sebagai berikut :

\section{Tabel 1. Efektivitas Pajak Hotel}

\begin{tabular}{|c|c|c|l|}
\hline Tahun & Target & Realisasi & Efektivitas \\
\hline 2013 & $979.825 .000,00$ & $987.174 .428,00$ & $100,75 \%$ \\
\hline 2014 & $944.793 .000,00$ & $990.699 .627,00$ & $104,86 \%$ \\
\hline 2015 & $982.561 .000,00$ & $1.082 .931 .478,00$ & $110,22 \%$ \\
\hline 2016 & $1.271 .858 .000,00$ & $1.941 .258 .818,00$ & $152,63 \%$ \\
\hline 2017 & $2.528 .000 .000,00$ & $2.744 .647 .609,00$ & $108,57 \%$ \\
\hline
\end{tabular}

Sumber : Data Diolah (2018)

Berdasarkan tabel 1 di atas dapat diketahui bahwa realisasi penerimaan pajak hotel selalu meningkat setiap tahunnya dan tingkat efektivitas pajak hotel di Kota Tegal selama periode tahun 2013 - 2017 lebih dari 100\% sehingga dikategorikan penerimaan pajak hotel sangat efektif. Hal tersebut menunjukkan bahwa realisasi penerimaan pajak hotel selalu mencapai target yang ditetapkan meskipun besaran target yang ditetapkan setiap tahun selalu meningkat.

Hal ini karena pihak Badan Keuangan Daerah Kota Tegal selalu berupaya untuk mencapai target penerimaan pajak dengan melaksanakan program kerja yang baik dan inovatif. Selain itu juga jumlah wajib pajak hotel selalu meningkat setiap tahunnya karena banyak berdiri hotel - hotel baru dan tingkat kepatuhannya 
juga baik sehingga dapat mencapai target penerimaan pajak hotel. Adapun tingkat efektivitas tertinggi terjadi pada tahun 2016 dengan tingkat efektivitas sebesar 152,63\%. Hal ini karena pada tahun 2016 banyak berdiri hotel - hotel baru di Kota Tegal sehingga berdampak terhadap jumlah wajib pajak hotel yang juga meningkat.

\subsection{Efektivitas Pajak Restoran}

Berdasarkan data target dan realisasi penerimaan pajak restoran selama periode tahun 2013 - 2017 maka dapat diketahui rasio efektivitas pajak restoran di Kota Tegal sebagai berikut :

Tabel 2. Efektivitas Pajak Restoran

\begin{tabular}{|c|c|c|c|}
\hline Thn & Target & Realisasi & Efektivitas \\
\hline 2013 & $2.732 .588 .000,00$ & $3.339 .014 .451,00$ & $122,19 \%$ \\
\hline 2014 & $3.809 .471 .000,00$ & $4.240 .060 .774,00$ & $111,30 \%$ \\
\hline 2015 & $4.104 .980 .000,00$ & $4.805 .739 .495,00$ & $117,07 \%$ \\
\hline 2016 & $4.925 .776 .000,00$ & $6.162 .073 .584,00$ & $125,10 \%$ \\
\hline 2017 & $8.500 .000 .000,00$ & $9.688 .703 .249,00$ & $113,98 \%$ \\
\hline
\end{tabular}

Sumber : Data Diolah (2018)

Berdasarkan tabel 2 diatas dapat diketahui bahwa realisasi penerimaan pajak restoran selalu meningkat setiap tahunnya dan tingkat efektivitas pajak restoran di Kota Tegal selama periode tahun 2013 - 2017 lebih dari 100\% sehingga dikategorikan penerimaan pajak restoran sangat efektif meskipun rasionya mengalami naik turun. Hal tersebut menunjukkan bahwa realisasi penerimaan pajak restoran selalu mencapai target yang ditetapkan meskipun besaran target yang ditetapkan setiap tahun selalu meningkat. Hal ini karena jumlah wajib pajak restoran selalu meningkat setiap tahunnya karena banyak berdiri cafe baru dan rumah makan baru dan tingkat kepatuhannya juga baik sehingga dapat mencapai target penerimaan. Selain itu, Badan Keuangan Daerah Kota Tegal sangat intensif mencari sasaran potensi wajib pajak restoran dan melakukan penagihan kepada wajib pajak restoran. Adapun tingkat efektivitas tertinggi terjadi pada tahun 2016 dengan tingkat efektivitas sebesar $125,10 \%$. Hal ini karena pada tahun 2016 banyak berdiri hotel yang membuka beberapa gerai makanan dan juga banyak cafe dan rumah makan baru di Kota Tegal sehingga jumlah wajib pajak hotel juga meningkat.

\subsection{Efektivitas Pajak Hiburan}

Berdasarkan data target dan realisasi penerimaan pajak hiburan selama periode tahun 2013 - 2017 maka dapat diketahui rasio efektivitas pajak hiburan di Kota Tegal sebagai berikut :
Tabel 3. Efektivitas Pajak Hiburan

\begin{tabular}{|c|r|r|r|}
\hline Tahun & \multicolumn{1}{|c|}{ Target } & \multicolumn{1}{|c|}{ Realisasi } & Efektivitas \\
\hline 2013 & $1.639 .876 .000,00$ & $880.735 .111,00$ & $53,71 \%$ \\
\hline 2014 & $1.009 .749 .000,00$ & $841.511 .307,00$ & $83,34 \%$ \\
\hline 2015 & $709.838 .000,00$ & $868.375 .794,00$ & $122,33 \%$ \\
\hline 2016 & $988.645 .000,00$ & $1.167 .676 .869,00$ & $118,11 \%$ \\
\hline 2017 & $2.977 .000 .000,00$ & $3.518 .805 .028,00$ & $118,20 \%$ \\
\hline
\end{tabular}

Sumber : Data Diolah (2018)

Berdasarkan tabel 3 diatas dapat diketahui bahwa target penerimaan pajak hiburan selama periode tahun 2013-2017 mengalami naik turun sehingga realisasi penerimaan pajak hiburan juga mengalami naik turun. Adapun tingkat efektivitas pajak hiburan pada tahun 2013 dan tahun 2014 masih dibawah $100 \%$ sehingga belum dikatakan sangat efektif. Akan tetapi mulai tahun 2015-2017 terjadi peningkatan tingkat efektivitasnya menjadi diatas $100 \%$ sehingga dapat dikatakan sangat efektif meskipun pada tahun 2015-2016 terjadi penurunan target penerimaan pajak hiburan. Pada tahun 2017 terjadi peningkatan yang signifikan dimana target dan realisasinya mengalami kenaikan $100 \%$ lebih dari periode tahun tahun sebelumnya. Hal ini karena pada tahun tersebut di Kota Tegal banyak berdiri tempat hiburan seperti karaoke, spa, bar, tempat hiburan anak - anak sehingga terjadi peningkatan jumlah wajib pajak yang sangat signifikan. Selain itu, Pemerintah Kota Tegal juga sangat tegas dalam menindak para wajib pajak tempat hiburan yang tidak patuh membayar pajak dengan mencabut izin operasionalnya sehingga hal tersebut membuat para wajib pajak hiburan mau membayar pajak hiburan.

\subsection{Kontribusi Pajak Hotel Terhadap PDRB}

Berdasarkan data realisasi penerimaan pajak hotel selama periode tahun 2013 - 2017 maka dapat diketahui rasio kontribusi pajak hotel terhadap PDRB atas harga berlaku di Kota Tegal sebagai berikut :

Tabel 4. Kontribusi Pajak Hotel Terhadap PDRB

\begin{tabular}{|c|r|r|r|}
\hline Thn & $\begin{array}{c}\text { Realisasi Pajak } \\
\text { Hotel }\end{array}$ & \multicolumn{1}{|c|}{ PDRB } & Kontribusi \\
\hline 2013 & $987.174 .428,00$ & 3.374 .653 .998 .580 & $0,029 \%$ \\
\hline 2014 & $990.699 .627,00$ & 3.709 .043 .130 .770 & $0,026 \%$ \\
\hline 2015 & $1.082 .931 .478,00$ & 10.781 .038 .180 .000 & $0,010 \%$ \\
\hline 2016 & $1.941 .258 .818,00$ & 11.886 .655 .930 .000 & $0,016 \%$ \\
\hline 2017 & $2.744 .647 .609,00$ & 12.579 .320 .060 .000 & $0,021 \%$ \\
\hline
\end{tabular}

Sumber : Data Diolah (2018) 
Berdasarkan tabel 4 di atas dapat diketahui bahwa pada tahun 2013 kontribusi pajak hotel terhadap PDRB sebesar 0,029\% dari total PDRB sebesar Rp. 3.374.653.998.580. Tahun 2014 kontribusi pajak hotel terhadap PDRB turun menjadi sebesar $0,026 \%$. Hal ini karena kenaikan pajak hotel sebesar $0,36 \%$ lebih kecil jika dibandingkan kenaikan PDRB sebesar 9,91\%. Kemudian tahun 2015 kontribusi pajak hotel terhadap PDRB turun lagi menjadi sebesar 0,010\%. Hal ini dipengaruhi oleh kenaikan pajak hotel sebesar 9,31\% lebih kecil jika dibandingkan kenaikan PDRB sebesar 191\%. Pada tahun 2016 kontribusi pajak hotel mengalami kenaikan menjadi $0,016 \%$. Hal ini dipengaruhi oleh naiknya penerimaan pajak hotel sebesar 79,26\% lebih besar dari pada kenaikan PDRB yang hanya naik 10,3\%. Pada tahun 2017 kontribusi pajak hotel terhadap PDRB kembali naik menjadi $0,021 \%$ karena dipengaruhi oleh naiknya penerimaan pajak hotel sebesar 41,38\% yang lebih besar dari pada kenaikan PDRB yang hanya naik 5,83\%.

Dengan demikian jika dirata-rata kontribusi pajak hotel terhadap PDRB selama periode tahun 2013- 2017 sebesar 0,0204\% per tahun. Jadi dapat disimpulkan bahwa kontribusi pajak hotel terhadap PDRB Kota Tegal masuk ketegori sangat kurang.

\subsection{Kontribusi Pajak Hotel Terhadap PAD}

Berdasarkan data realisasi penerimaan pajak hotel selama periode tahun 2013 - 2017 maka dapat diketahui rasio kontribusi pajak hotel terhadap PAD Kota Tegal sebagai berikut :

Tabel 5. Kontribusi Pajak Hotel Terhadap PAD Kota Tegal

\begin{tabular}{|c|c|c|r|}
\hline Thn & $\begin{array}{c}\text { Realisasi Pajak } \\
\text { Hotel }\end{array}$ & PAD & Kontribusi \\
\hline 2013 & $987.174 .428,00$ & $176.377 .335 .075,00$ & $0,55 \%$ \\
\hline 2014 & $990.699 .627,00$ & $241.936 .166 .929,00$ & $0,40 \%$ \\
\hline 2015 & $1.082 .931 .478,00$ & $271.601 .407 .419,00$ & $0,39 \%$ \\
\hline 2016 & $1.941 .258 .818,00$ & $287.343 .889 .954,00$ & $0,67 \%$ \\
\hline 2017 & $2.744 .647 .609,00$ & $306.830 .528 .134,99$ & $0,89 \%$ \\
\hline
\end{tabular}

Sumber : Data Diolah (2018)

Berdasarkan tabel 5 diatas dapat diketahui bahwa pada tahun 2013 kontribusi pajak hotel terhadap PAD sebesar 0,55\% dari total PAD sebesar Rp. 176.377.335.075. Tahun 2014 kontribusi pajak hotel terhadap PAD turun menjadi sebesar $0,40 \%$. Hal ini karena kenaikan pajak hotel sebesar 0,36\% lebih kecil jika dibandingkan kenaikan PAD sebesar $37,17 \%$. Kemudian tahun
2015 kontribusi pajak hotel terhadap PAD turun lagi menjadi sebesar 0,39\%. Hal ini dipengaruhi oleh kenaikan pajak hotel sebesar 9,31\% lebih kecil jika dibandingkan kenaikan PAD sebesar 12,26\%. Pada tahun 2016 kontribusi pajak hotel mengalami kenaikan menjadi $0,67 \%$. Hal ini dipengaruhi oleh naiknya penerimaan pajak hotel sebesar 79,26\% lebih besar dari pada kenaikan PAD yang hanya naik 5,80\%. Pada tahun 2017 kontribusi pajak hotel terhadap PAD kembali naik menjadi 0,89\% karena dipengaruhi oleh naiknya penerimaan pajak hotel sebesar $41,38 \%$ yang lebih besar dari pada kenaikan PAD yang hanya naik $6,78 \%$.

Dengan demikian jika dirata-rata kontribusi pajak hotel terhadap PAD selama periode tahun 2013- 2017 sebesar 0,58\% per tahun. Jadi dapat disimpulkan bahwa kontribusi pajak hotel terhadap PAD Kota Tegal masuk ketegori sangat kurang.

\subsection{Kontribusi Pajak Restoran Terhadap PDRB}

Berdasarkan data realisasi penerimaan pajak restoran selama periode tahun 2013 - 2017 maka dapat diketahui rasio kontribusi pajak restoran terhadap PDRB atas harga berlaku sebagai berikut :

Tabel 6. Kontribusi Pajak Restoran Terhadap PDRB Kota Tegal

\begin{tabular}{|c|c|c|c|}
\hline Thn & $\begin{array}{c}\text { Realisasi } \\
\text { Pajak Restoran }\end{array}$ & PDRB & Kontribusi \\
\hline 2013 & $3.339 .014 .451,00$ & 3.374 .653 .998 .580 & $0,098 \%$ \\
\hline 2014 & $4.240 .060 .774,00$ & 3.709 .043 .130 .770 & $0,114 \%$ \\
\hline 2015 & $4.805 .739 .495,00$ & 10.781 .038 .180 .000 & $0,044 \%$ \\
\hline 2016 & $6.162 .073 .584,00$ & 11.886 .655 .930 .000 & $0,051 \%$ \\
\hline 2017 & $9.688 .703 .249,00$ & 12.579 .320 .060 .000 & $0,077 \%$ \\
\hline
\end{tabular}

Sumber : Data Diolah (2018)

Berdasarkan tabel 6 diatas dapat diketahui bahwa pada tahun 2013 kontribusi pajak restoran terhadap PDRB sebesar 0,098\% dari total PDRB sebesar Rp. 3.374.653.998.580. Tahun 2014 kontribusi pajak restoran terhadap PDRB naik menjadi sebesar $0,114 \%$. Hal ini karena kenaikan pajak restoran sebesar 26,99\% lebih besar jika dibandingkan kenaikan PDRB sebesar 9,91\%. Kemudian tahun 2015 kontribusi pajak restoran terhadap PDRB turun menjadi sebesar 0,044\%. Hal ini dipengaruhi oleh kenaikan pajak restoran sebesar 13,34\% lebih kecil jika dibandingkan kenaikan PDRB sebesar 191\%. Pada tahun 2016 kontribusi pajak restoran mengalami kenaikan menjadi $0,051 \%$. Hal ini dipengaruhi oleh naiknya 
penerimaan pajak restoran sebesar 28,22\% lebih besar dari pada kenaikan PDRB yang hanya naik 10,3\%. Pada tahun 2017 kontribusi pajak restoran terhadap PDRB kembali naik menjadi 0,077\% karena dipengaruhi oleh naiknya penerimaan pajak restoran sebesar $57,23 \%$ yang lebih besar dari pada kenaikan PDRB yang hanya naik 5,83\%.

Dengan demikian jika dirata-rata kontribusi pajak restoran terhadap PDRB selama periode tahun 2013- 2017 sebesar 0,0768\% per tahun. Jadi dapat disimpulkan bahwa kontribusi pajak restoran terhadap PDRB Kota Tegal masuk ketegori sangat kurang.

\subsection{Kontribusi Pajak Restoran Terhadap PAD}

Berdasarkan data realisasi penerimaan pajak restoran selama periode tahun 2013 - 2017 maka dapat diketahui rasio kontribusi pajak restoran terhadap PAD sebagai berikut :

Tabel 7. Kontribusi Pajak Restoran Terhadap PAD Kota Tegal

\begin{tabular}{|c|c|c|c|}
\hline Thn & $\begin{array}{c}\text { Realisasi } \\
\text { Pajak Restoran }\end{array}$ & PAD & $\begin{array}{c}\text { Kontri } \\
\text { busi }\end{array}$ \\
\hline 2013 & $3.339 .014 .451,00$ & $176.377 .335 .075,00$ & $1,89 \%$ \\
\hline 2014 & $4.240 .060 .774,00$ & $241.936 .166 .929,00$ & $1,75 \%$ \\
\hline 2015 & $4.805 .739 .495,00$ & $271.601 .407 .419,00$ & $1,76 \%$ \\
\hline 2016 & $6.162 .073 .584,00$ & $287.343 .889 .954,00$ & $2,14 \%$ \\
\hline 2017 & $9.688 .703 .249,00$ & $306.830 .528 .134,99$ & $3,15 \%$ \\
\hline & & & \\
\hline
\end{tabular}

Sumber : Data Diolah (2018)

Berdasarkan tabel 7 diatas dapat diketahui bahwa pada tahun 2013 kontribusi pajak restoran terhadap PAD sebesar 1,89\% dari total PAD sebesar Rp. 176.377.335.075. Tahun 2014 kontribusi pajak restoran terhadap PAD turun menjadi sebesar $1,75 \%$. Hal ini karena kenaikan pajak restoran sebesar 26,99\% lebih kecil jika dibandingkan kenaikan PAD sebesar 37,17\%. Kemudian tahun 2015 kontribusi pajak restoran terhadap PAD naik menjadi sebesar $1,76 \%$. Hal ini dipengaruhi oleh kenaikan pajak restoran sebesar 13,34\% lebih besar jika dibandingkan kenaikan PAD sebesar 12,26\%. Pada tahun 2016 kontribusi pajak restoran mengalami kenaikan menjadi $2,14 \%$. Hal ini dipengaruhi oleh naiknya penerimaan pajak restoran sebesar 28,22\% lebih besar dari pada kenaikan PAD yang hanya naik 5,80\%. Pada tahun 2017 kontribusi pajak restoran terhadap PAD kembali naik menjadi 3,15\% karena dipengaruhi oleh naiknya penerimaan pajak restoran sebesar $57,23 \%$ yang lebih besar dari pada kenaikan PAD yang hanya naik $6,78 \%$.

Dengan demikian jika dirata-rata kontribusi pajak restoran terhadap PAD selama periode tahun 20132017 sebesar $2,138 \%$ per tahun. Jadi dapat disimpulkan bahwa kontribusi pajak restoran terhadap PAD Kota Tegal masuk ketegori sangat kurang.

\subsection{Kontribusi Pajak Hiburan Terhadap PDRB}

Berdasarkan data realisasi penerimaan pajak hiburan selama periode tahun 2013 - 2017 maka dapat diketahui rasio kontribusi pajak hiburan terhadap PDRB atas harga berlaku sebagai berikut :

Tabel 8. Kontribusi Pajak Hiburan Terhadap PDRB Kota Tegal

\begin{tabular}{|c|c|c|r|}
\hline Thn & $\begin{array}{c}\text { Realisasi } \\
\text { Pajak Hiburan }\end{array}$ & \multicolumn{1}{|c|}{ PDRB } & Kontribusi \\
\hline 2013 & $880.735 .111,00$ & 3.374 .653 .998 .580 & $0,026 \%$ \\
\hline 2014 & $841.511 .307,00$ & 3.709 .043 .130 .770 & $0,022 \%$ \\
\hline 2015 & $868.375 .794,00$ & 10.781 .038 .180 .000 & $0,008 \%$ \\
\hline 2016 & $1.167 .676 .869,00$ & 11.886 .655 .930 .000 & $0,009 \%$ \\
\hline 2017 & $3.518 .805 .028,00$ & 12.579 .320 .060 .000 & $0,027 \%$ \\
\hline
\end{tabular}

Sumber : Data Diolah (2018)

Berdasarkan tabel 8 diatas dapat diketahui bahwa pada tahun 2013 kontribusi pajak hiburan terhadap PDRB sebesar 0,026\% dari total PDRB sebesar Rp. 3.374.653.998.580. Tahun 2014 kontribusi pajak hiburan terhadap PDRB turun menjadi sebesar $0,022 \%$. Hal ini karena terjadi penurunan pajak hiburan sebesar $4,45 \%$ sedangkan PDRB mengalami kenaikan sebesar 9,91\%. Kemudian tahun 2015 kontribusi pajak hiburan terhadap PDRB turun menjadi sebesar 0,008\%. Hal ini dipengaruhi oleh kenaikan pajak hiburan sebesar 3,19\% yang jauh lebih kecil jika dibandingkan kenaikan PDRB sebesar 191\%. Pada tahun 2016 kontribusi pajak hiburan mengalami kenaikan yang tidak signifikan menjadi $0,009 \%$. Hal ini dipengaruhi oleh naiknya penerimaan pajak hiburan sebesar $34,47 \%$ lebih besar dari pada kenaikan PDRB yang hanya naik 10,3\%. Pada tahun 2017 kontribusi pajak hiburan terhadap PDRB kembali naik menjadi 0,027\% karena dipengaruhi oleh naiknya penerimaan pajak hiburan sebesar 201,35\% yang jauh lebih besar daripada kenaikan PDRB yang hanya naik 5,83\%.

Dengan demikian jika dirata-rata kontribusi pajak hiburan terhadap PDRB selama periode tahun 2013- 2017 sebesar 0,0184\% per 
tahun. Jadi dapat disimpulkan bahwa kontribusi pajak restoran terhadap PDRB Kota Tegal masuk ketegori sangat kurang.

\subsection{Kontribusi Pajak Hiburan Terhadap PAD}

Berdasarkan data realisasi penerimaan pajak hiburan selama periode tahun 2013 - 2017 maka dapat diketahui rasio kontribusi pajak hiburan terhadap PAD sebagai berikut :

Tabel 9. Kontribusi Pajak Hiburan Terhadap PAD Kota Tegal

\begin{tabular}{|l|l|l|c|}
\hline Thn & $\begin{array}{l}\text { Realisasi } \\
\text { Pajak Hiburan }\end{array}$ & PAD & Kontribusi \\
\hline 2013 & $880.735 .111,00$ & $176.377 .335 .075,00$ & $0,49 \%$ \\
\hline 2014 & $841.511 .307,00$ & $241.936 .166 .929,00$ & $0,34 \%$ \\
\hline 2015 & $868.375 .794,00$ & $271.601 .407 .419,00$ & $0,32 \%$ \\
\hline 2016 & $1.167 .676 .869,00$ & $287.343 .889 .954,00$ & $0,40 \%$ \\
\hline 2017 & $3.518 .805 .028,00$ & $306.830 .528 .134,99$ & $1,14 \%$ \\
\hline
\end{tabular}

Sumber : Data Diolah (2018)

Berdasarkan tabel 9 diatas dapat diketahui bahwa pada tahun 2013 kontribusi pajak hiburan terhadap PAD sebesar 0,49\% dari total PAD sebesar Rp. 176.377.335.075. Tahun 2014 kontribusi pajak hiburan terhadap PAD turun menjadi sebesar $0,34 \%$. Hal ini karena terjadi penurunan pajak hiburan sebesar $4,45 \%$ sedangkan PAD mengalami kenaikan sebesar $37,17 \%$. Kemudian tahun 2015 kontribusi pajak hiburan terhadap PAD turun menjadi sebesar $0,32 \%$. Hal ini dipengaruhi oleh kenaikan pajak hiburan sebesar 3,19\% yang jauh lebih kecil jika dibandingkan kenaikan PAD sebesar 12,26\%. Pada tahun 2016 kontribusi pajak hiburan mengalami kenaikan menjadi sebesar $0,40 \%$. Hal ini dipengaruhi oleh naiknya penerimaan pajak hiburan sebesar 34,47\% lebih besar dari pada kenaikan PAD yang hanya naik 5,80\%. Pada tahun 2017 kontribusi pajak hiburan terhadap PAD kembali naik menjadi $1,14 \%$ karena dipengaruhi oleh naiknya penerimaan pajak hiburan sebesar $201,35 \%$ yang jauh lebih besar daripada kenaikan PDRB yang hanya naik $6,78 \%$.

Dengan demikian jika dirata-rata kontribusi pajak hiburan terhadap PDRB selama periode tahun 2013- 2017 sebesar 0,538\% per tahun. Jadi dapat disimpulkan bahwa kontribusi pajak restoran terhadap PAD Kota Tegal masuk ketegori sangat kurang.

\section{KESIMPULAN DAN SARAN \\ Kesimpulan}

Berdasarkan hasil penelitian dan pembahasan maka dapat diambil kesimpulan dalam penelitian ini sebagai berikut :

1. Efektivitas penerimaan pajak hotel di Kota Tegal selama periode tahun 2013 - 2017 memiliki rasio lebih dari $100 \%$ sehingga dapat dikatakan sangat efektif.

2. Efektivitas penerimaan pajak restoran di Kota Tegal selama periode tahun 2013 - 2017 memiliki rasio lebih dari $100 \%$ sehingga dapat dikatakan sangat efektif.

3. Efektivitas penerimaan pajak hiburan di Kota Tegal selama periode tahun 2013 - 2017 mengalami perubahan tiap tahunnya. Pada tahun 2013 rasio efektivitas penerimaan pajak hiburan sebesar $53,71 \%$ sehingga dikatakan tidak efektif. Kemudian pada tahun 2014, rasio efektivitas penerimaan pajak hiburan sebesar $83,34 \%$ sehingga dikatakan cukup efektif. Sedangkan pada tahun 2015 - 2017, rasio efektivitas penerimaan pajak hiburan lebih dari $100 \%$ sehingga dikatakan sangat efektif.

4. Kontribusi pajak hotel, pajak restoran dan pajak hiburan terhadap Produk Domestik Regional Bruto (PDRB) Kota Tegal selama periode tahun 2013 - 2017 dengan rasio kontribusi masih dibawah $10 \%$ sehingga dikatakan sangat kurang.

5. Kontribusi pajak hotel, pajak restoran dan pajak hiburan terhadap Pendapatan Asli Daerah (PAD) Kota Tegal selama periode tahun 2013 2017 dengan rasio kontribusi masih dibawah $10 \%$ sehingga dikatakan sangat kurang.

\section{Saran}

Berdasarkan kesimpulan diatas maka saran yang dapat diberikan yaitu sebagai berikut :

1. Badan Keuangan Daerah Kota Tegal untuk dapat meningkatkan potensi jumlah wajib pajak daerah yang belum terdaftar sehingga dapat memberikan kontribusi bagi penerimaan pajak daerah

2. Badan Keuangan Daerah Kota Tegal untuk dapat meningkatkan kepatuhan wajib pajak daerah dan memberikan sangsi yang tegas apabila para wajib pajak terlambat atau tidak membayar pajak daerah.

3. Badan Keuangan Daerah untuk dapat meningkatkan pelayanan kepada wajib pajak daerah terutama berkaitan dengan kemudahan 
dalam proses pembayaran dan pendaftaran sebagai wajib pajak daerah.

4. Para wajib pajak daerah untuk dapat berperan aktif dalam membayar pajak daerah sehingga dapat memberikan kontribusi yang besar terhadap penerimaan Pendapatan Asli Daerah.

5. Bagi peneliti selanjutnya untuk dapat mengkaji lebih lanjut tentang pajak daerah dan kontribusinya terhadap Produk Domestik Regional Bruto dan Pendapatan Asli Daerah dengan menggunakan analisis yang lebih mendalam.

\section{DAFTAR PUSTAKA}

[1] Erawati dan Rahmawati. 2016. Analisis Efektifitas Dan Efisiensi Pajak Reklame, Pajak Parkir, Pajak Hiburan, Produk Domestik Regional Bruto (PDRB) Dan Pendapatan Asli Daerah (PAD) Di Kabupaten Bantul. Jurnal Akuntansi Vol. 4 No. 1 Juni 2016 Program Studi Akuntansi Fakultas Ekonomi Universitas Sarjanawiyata Tamansiswa

[2] Arianto dan Padmono. 2014. Faktor-Faktor Yang Mempengaruhi Penerimaan Pajak Daerah Di Kota Surabaya. Jurnal Ilmu \& Riset Akuntansi Vol. 3 No. 1. Sekolah Tinggi Ilmu Ekonomi Indonesia (STIESIA) Surabaya

[3] Haniz, Nadya Fazriana. 2013. Analisis Faktor-Faktor Yang Mempengaruhi Penerimaan Pajak Daerah Kota Tegal. Skripsi. Fakultas Ekonomika Dan Bisnis Universitas Diponegoro

[4] Resmi, Siti. 2017. Perpajakan : Teori Dan Kasus. Jakarta. Penerbit Salemba Empat

[5] Undang - Undang Nomor 28 Tahun 2009 Tentang Pajak Daerah Dan Retribusi Daerah

[6] Nurrohman, Alfian. 2010. Analisis FaktorFaktor Yang Mempengaruhi Penerimaan Pajak Daerah Di Kota Surakarta (Tahun 1994-2007). Skripsi. Fakultas Ekonomi Universitas Sebelas Maret Surakarta

[7] Khotijah, Siti. 2017. Analisis Faktor-Faktor Yang Mempengaruhi Pendapatan Asli Daerah Di Provinsi Yogyakarta Tahun 20102015. Skripsi. Prodi Ekonomi Pembangunan
- S1 Fakultas Ekonomi Dan Bisnis Universitas Muhammadiyah Surakarta

[8] Prasetyo, Masitoh dan Dewi. 2017. FaktorFaktor Yang Mempengaruhi Penerimaan Pajak Reklame Di Kabupaten Karanganyar. Seminar Nasional IENACO - 2017 Program Studi Akuntansi Fakultas Ekonomi Universitas Islam Batik.

[9] Peraturan Daerah Kota Tegal No. 5 Tahun 2011 Tentang Pajak Daerah

[10] Abdul Halim, dkk. 2014. Perpajakan Konsep, Aplikasi, Contoh, dan Studi Kasus. Jakarta : Salemba Empat

[11] Helti, Kristiana Advina. 2010. Analisis Faktor-Faktor Yang Mempengaruhi Pajak Daerah Serta Tingkat Efisiensi Dan Efektivitas Dalam Pemungutan (Studi Kasus di Kabupaten Karanganyar). Skripsi. Fakultas Ekonomi Universitas Sebelas Maret Surakarta

[12] Sugiono. 2012. Metode Penelitian Bisnis. CV. Alfabeta. Bandung

[13] Undang-Undang Nomor 32 Tahun 2004 tentang Pemerintahan Daerah

[14] Undang-Undang Nomor 33 Tahun 2004 tentang Perimbangan Keuangan Antara Pemerintah Pusat dan Pemerintahan Daerah 